https://doi.org/10.48009/2_iis_2009_22-26

\title{
ONLINE SHOPPING PERCEPTIONS OF OFFLINE SHOPPERS
}

\author{
Manouchehr Tabatabaei, Georgia Southern University, mtabatab@georgiasouthern.edu
}

\begin{abstract}
Recent advancements in technology have facilitated commerce around the globe. The online medium of commerce has provided and will continue to provide great opportunities for consumers and businesses. However, there are a number of issues that need to be addressed before the advantages of online shopping can be fully realized. One significant aspect is consumer perception of online shopping. The purpose of this paper is to examine the online shopping perception of consumers who shop from traditional stores. A survey was conducted in shopping malls in the southeastern region of the United States. The results show a positive perception of offline consumers toward online shopping. In addition, the results coincide with national trends for online shopping which show many traditional shoppers gather information on products and services online, but still make the purchase onsite in a traditional setting by visiting a store.
\end{abstract}

Keywords: Perception of consumers, Online shopping, Offline shopping

\section{INTRODUCTION}

The rise in internet access and online commerce possibilities in recent years has made online shopping a major opportunity for businesses and has changed the way that consumers go about acquiring goods and services (Garrett and Parrott 2005; Schoenbachler and Gordon 2002). For consumers, online shopping provides more flexibility and opportunity (Stafford, Turan, and Raisinghani 2004). For example, consumers can shop with increased knowledge of products through online research and place less reliance on salespersons. If they wish to make a purchase, consumers are not restricted by time, distance, or location (Kim and Kim 2004; Schoenbachler and Gordon 2002). Furthermore, online stores do not incur costs such as store staffing, maintenance, and inventory and might be able to specialize in items and extreme sizes that would not be practical for traditional stores to carry. Amazon and eBay are examples of successful online retailers that use low-priced items and large stocks to attract and retain customers.

Online commerce is expanding and is attracting increasing numbers of customers. Many traditional businesses are reacting by going online to remain competitive (Schoenbachler and Gordon 2002). Advancements in technology enable apparel stores, for instance, to improve their online services by using personalized virtual models allowing consumers to visualize the product on the model to determine correct sizing and fit (Kim and Kim 2004; for a trend forecast of the online apparel industry, see: Newbery 2004). In general, online businesses such as Dell are able to mass customize because of current technology and offer customers basically a build-to-order service. Retail based e-commerce sites also try to serve customers by providing a personal shopper. As the shopper searches for an item of interest online, similar or complementing products are suggested. This personal one-on-one customized assistance might require more knowledgeable staff in a traditional store and might require an increase in the costs of products to compensate for the increased staffing costs.

The internet has influenced the life of everyone in the recent years and has impacted behavior of consumers (Garrett and Parrott 2005). In general, three types of consumers in regard to their shopping habits can be classified (Lepkowska-White 2004):

- Online shoppers, i.e. those who purchase regularly online

- Online browsers, who mainly use the internet as a source of information but prefer to conduct their transactions in traditional stores

- Hard core offline shoppers, comprised of the continuously diminishing group of individuals, who do not use the resources of the internet either for information gathering or for shopping purposes

These different groups show different characteristics and will need to be addressed differently to optimize or initiate online shopping behavior.

This study focuses on the traditional consumers who prefer shopping onsite. It is important to know their perception toward online shopping and their classifications of online browsers or hard core offline shoppers. In addition, the factors preventing them from shopping online are important to understand. 
The findings of this study should help motivating and encouraging more people to shop online. Reasons for not shopping online might include a lack of interest and knowledge about computers or the internet or going online for research purposes only. The foregoing discussion therefore suggests the following research questions (RQs):

RQ1: Are offline shoppers computer and internet literate?

RQ2: Do offline shoppers go online?

RQ3: Do offline shoppers access the internet for purposes other than purchasing?

RQ4: Are there certain distinguishing characteristics between online and traditional shoppers (defined as online browsers and offline shoppers) in regard to online shopping?

In order to answer the above RQs the following two major hypotheses are tested.

H01: Offline shoppers are computer and internet illiterate

H02: Offline shoppers do not go online

\section{RELATED LITERATURE}

The number of internet users and online shoppers are increasing significantly every year. U.S. consumers are spending billions of dollars online each year (Preston-Hubbard, 2004). The internet retail sale is increasing rapidly to the extent that this increase is realized and measured by quarter and not year. (Tamini, Sebastianelli, and Rajan 2005). Currently, many Americans have internet access and the number of households to have access to internet will increase significantly in the years to come (Lepkowska-White 2004). An increasing percentage of those who are currently connected, shop online, i.e. use the internet to complete at least one purchase per month (Lepkowska-White 2004). Similar numbers are available for the European market, where, a significant number of internet users are shopping online (Monsuwe, Dellaert, and Ruyter 2004). For example, in Germany, retail sales of textiles, electronic products and durables via the internet has increased significantly in recent years (Reinhardt 2004).

A significantly higher number of individuals, sometimes referred to as online browsers in the literature (e.g. Lepkowska-White 2004), avail themselves of the resources provided by the internet to check products or compare prices (Jaillet 2003). A study by Pew Internet and American Life Project suggests that most online browsers need about one to three years to become online shoppers (LepkowskaWhite 2004). Depending on how many of those individuals can be turned into online shoppers, predictions for online sales vary widely from $\$ 81$ billion in 2005 (Bellman, Lohse, and Johnson 1999; Monsuwe, Dellaert, and Ruyter 2004) to as much as \$269 billion in 2006 (Lepkowska-White 2004). Consequently, there is a huge market to be explored. However, businesses must be aware of perceptions and concerns regarding online shopping of traditional shoppers, and the online browsers.

In order to capitalize on this potential in the best possible way, various models and frameworks for analysis have been presented in the recent literature on the topic (Chiang, Dholakia 2003; Zhou, Chiang, Zhang 2004). Monsuwe, Dellaert, and Ruyter (2004) have suggested a framework for consumers' intentions to shop online which draws on the Technology Acceptance Model (TAM), popular in the field of Information Systems. According to this framework, utilitarian dimensions such as usefulness and ease of use of the site and hedonic dimensions such as enjoyment together with the consumer's traits shape the consumer's attitude towards online shopping. Situational factors trust in online shopping, product characteristics and previous online shopping experience affect the final decision to conclude the transaction online or not. Lepkowska-White (2004) divides variables for the analysis of online shopping behavior into supply and demand factors, with supply factors meaning web design and technical aspects and demand factors referring to consumer factors, such as social interaction, and product/service determinants, such as selection of products available online.

Despite different naming conventions, the literature on the topic agrees that the 24/7 availability of products and information about products have changed the retail industry and consumer shopping. Most stores feel they cannot afford not to be online, even if for information purposes only (Schoenbachler and Gordon 2002). Generally, time and location constraints, convenience, availability of products, incentive programs and easy comparison of product information induce shoppers to shop online (Huang, Schrank, Dubinsky 2004; Kim and Kim 2004; Levin, Levin, and Heath 2003). Shoppers are looking for hassle free, accurate transactions, proper display of sufficient information and efficient download times for sites in their online experience (Tamini, Sebastianelli, and Rajan 2005). Regarding price, the literature cites both lower prices as incentives for shopping online (GfK 2004; Girard, Silverblatt, and Korgaonkar 2002; Kim and Kim 2004) as well as a lesser degree of price sensitivity of online shoppers 
due to the added convenience. In addition, online browsers display a higher degree of price sensitivity compared to online shoppers but lesser degree of time sensitivity (Lepkowska-White 2004).

The demographic information on online shoppers is inconsistent in the literature. For example, Kim \& Kim (2004), report $43 \%$ of their respondents held graduate degrees while $12.41 \%$ of respondents in Tamini, Sebastianelli, and Rajan's (2005) study held graduate degrees. It seems, however, that most online shoppers have a higher level of education and higher incomes, with the average household income of online shoppers expected to be $\$ 65,000$ by 2006 (Kim and Kim 2004). While currently the majority of online shoppers is aged 44 or under (Kim \& Kim 2004), shoppers aged 50 years and over are expected to become a more significant portion of the online shopping population, increasing to $30 \%$ by 2006 (Anonymous 2002). Regarding gender, research suggests that while men were early adopters of online shopping behavior, women have caught up and online shopping is starting to display the same gender proportion as offline shopping does (Kim and Kim 2004; Lepkowska-White 2004; Stafford, Turan and Raisinghani 2004; Tamini, Sebastianelli and Rajan 2005; Van Slyke, Comunale, and Belanger 2002). Previous positive experience with online shopping, trust in the company shopped from, and sufficient customer service enhance positive attitudes towards online shopping as well as conviction of one's ability in one's computer skills and access to computers and the internet (Levin, Levin, and Heath 2003).

Generally, the greatest obstacles to getting individuals to shop online are hedonic dimensions of the shopping experience, security concerns and a lack of confidence in their computer skills (Swinyard and Smith 2003). The majority of those, who value the social components of the traditional shopping experience, such as interaction with sales people, window shopping, meeting up with peers and friends or the benefit of obtaining the product immediately, spend less time engaging in online shopping (Lepkowska-White 2004). Similarly, despite increased attempts at better security, credit card and personal information security are still a main concern for most shoppers: approximately 500 emails per day report online fraud to the Securities and Exchange Commission and average losses from online fraud have risen from $\$ 318$ per person in 2000 to $\$ 638$ in 2001 (Sager and Green 2002; Lepkowska-White 2004). Finally, individuals who do not complete transactions online indicated a lower level of confidence in their computer skills (LepkowskaWhite 2004).
In order to retain current and attract new online customers, online stores should ensure sufficient product information, such as displaying price and the product details as well as a well operational, current, user friendly and easy to download web sites (Chiang and Dholakis 2003). Security and accurate and comprehensive cost information positively skew the customer perception of the online shopping experience as well as good customer service and hassle free return policies (Tamimi, Sebastianelli, and Rajan 2005). Providing free shipping might prove a powerful incentive to increase the number of persons who complete an online purchase: a 2002 study found that shipping costs were the deterrent for $53 \%$ of individuals in the US who decided against an online purchase in the last steps of the process (Kim and Kim 2004).

\section{METHODOLOGY}

A survey was randomly administered at shopping malls in the southeastern region of the United States. A survey instrument was developed to determine the perception of consumers who enjoy shopping from traditional stores about online shopping. The survey was not conducted online to better target the offline shoppers. 264 surveys were used for the purpose of data analysis. Fourteen surveys had to be discarded since they were incomplete or instructions had not been followed. The survey consisted of components such as demographics, computer and internet literacy, perception which included attitude and behavior.

\section{FINDINGS}

The largest group of respondents was aged 18-30 $(35.7 \%)$, and the next largest group was individuals aged 61 and over $(28.3 \%)$. Of the 264 respondents, $32.6 \%$ were male. The most common response, given by slightly less than $30 \%$ of the respondents, indicated they were shopping online one to five times per year which further confirms the respondents of this study to be primarily offline shoppers. Online shoppers are assumed to shop online more than once a month (Lepkowska-White 2004).

The consumers of this study were overwhelmingly computer literate and had access to the internet $(84.5 \%)$. However, they were shopping in shopping malls (RQ1). Therefore, H01 is rejected and there is evidence that the offline shoppers of this study are in fact computer and internet literate. Many of them indicated they were going online (RQ2) to collect information and do research on products to be better prepared shoppers before purchasing items in 
traditional stores (72.4\%) (RQ3). Only a small number of these consumers purchased the product online ( 1 to 5 times a year) after they found the searched product $(32.3 \%)$ (RQ4). Therefore, H02 is also rejected and the contention offline shoppers of this study do in fact go online is supported.

It is clear that the consumers of this study shop offline. However, a small number of them $32.3 \%$ while searching for information on different products online ended up purchasing the product online one to five times per year (29.7\%). These individual cited the following reasons for completing the transaction online and purchasing the product they were researching for online: Familiarity with the online stores, No brick-and-mortar alternative (e-Bay, Amazon), Low-ticketed items. In addition, they considered ease of return the online-purchased item, and they thought the design of website was influential in their decision of finalizing the transaction and purchasing the product online.

\section{DISCUSSION OF FINDINGS}

Online shopping has already influenced shopping patterns and is expected to influence even more in the future with improvements in technology. Online shopping has made shoppers more knowledgeable than ever before. Consumers are becoming more efficient by shopping online and more effective because of ease of information accessibility online. Many shoppers go online for research purpose rather than purchase purpose. Prices and features of products can easily be compared to make an informed purchase decision. Information on products can be obtained from anywhere at anytime. The purchase is then made online or from a more tradition store. Especially for more expensive purchases, shoppers tend to take advantage of the availability of information online, replacing traditional methods of going from store to store in order to compare prices and look for the best buy.

Consumers in this study as expected were mainly offline shoppers who were browsing the internet for information. They were computer literate and had access to the internet. This study reveals a positive attitude toward online shopping by those consumers who still like traditional stores. The consumers of this study are mostly in low and high age groups. It is possible that these consumer groups place a stronger emphasis on the social aspects of offline shopping and have more time to spend in traditional stores and malls and value the offline shopping experience for social reasons, such as meeting with friends. These consumers are technology oriented and take advantage of technology and the internet to educate themselves about products of interest and then purchase them from traditional stores.

\section{CONCLUSION, LIMITATIONS, AND FUTURE WORKS}

Online shopping is a relatively new experience and has greatly impacted the lives of consumers in its short time of existence (Garrett \& Parrott 2005). It is expected to grow constantly in years to come with more advancement in technology. Online shopping has made consumers more effective and efficient in their shopping behavior and has driven businesses to a new level, forcing many to make the necessary adjustments and changes to reach the new market of knowledgeable consumers (Lepkowska-White 2004; Schaupp and Bélanger 2005). Tomorrow's consumers include today's elementary and secondary school students who grow up using browsers and search tools in order to retrieve information from global resources.

The offline shoppers of this study indicated a positive perception of online shopping. These offline shoppers collected the necessary information online to facilitate their offline shopping, and it seems they are not too far away from completing the transaction and making the purchase online. It is important for businesses to find the online analogy of factors that make customers buy in a brick-and-mortar setting (Lepkowska-White 2004).

Future studies should look into the factors preventing the current offline shoppers and online browsers from completing the transaction online after they have gained more knowledge about the product of interest. Factors encouraging individuals to complete a transaction online should be investigated. Future studies should also focus on what needs to be done in order to make the idea of online shopping in general more appealing to offline shoppers to turn more offline shoppers into online shoppers. In addition, perception of online shoppers toward traditional stores and onsite shopping should be considered. A perception comparison of online and offline shoppers on the internet and online shopping in general would facilitate understanding of restraining and motivational factors in online shopping. This survey was conducted in one region and future works should focus on different regions and classifications of consumers based on demographic make up such as age, income, and occupation. Cultural differences and online shopping would also be a good factor to examine (see for instance: Bin, Chen, and Sun 2003; Stafford, Turan and Raisinghani 2004). 


\section{REFERENCES}

1. Anonymous, 2002, Online Shoppers Grow Up Marketing Management, 11(3), 4.

2. Bellman, S, G. L. Lohse, and E. J. Johnson, 1999, Predictors of Online Buying Behavior, Communications of the ACM, 42(12), 32-38.

3. Bin, Q., C. Shu-Jen and S. Sun, 2003, Cultural Differences in E-Commerce: A Comparison Between the U.S. and China, Journal of Global Information Management, 11(2), 48-56.

Chiang, K. and Ruby R. Dholakia, 2003, Factors Driving Consumer Intention to Shop Online: An Empirical Investigation, Journal of Consumer Psychology, 13(1, 2), 98-105.

4. Garrett, G. and G. Parrott, 2005, E-Business: Understanding Key Trends and Applying Best Practices, Contract Management, 45(7), 34-42.

5. GfK Group, 2004, Market for Online Shopping Grows, Retrieved from: http://www.gfk.com/english/presse/pressemeldun g/contentdetail.php

6. Girard, T., R. Silverblatt, and P. Korgaonkar, 2002, Influence of Product Class on Preference for Shopping on the Internet, Journal of Computer-Mediated Communication, 8, 1-22.

7. Huang, W., H. Schrank and A.J. Dubinsky, 2004, Effect of Brand Name on Consumers' Risk Perceptions of Online Shopping, Journal of Consumer Behavior, 4(1), 40-51.

8. Jaillet, H.F., 2003, Web Metrics: Measuring Patterns in Online Shopping, Journal of Consumer Behavior, 2(4), 369-382.

9. Kim E.Y. and Y. Kim., 2004, Predicting Online Purchase Intentions for Clothing Products, European Journal of Marketing, 38(7), 883-898.

10. Lepkowska-White, E., 2004, Online Store Perceptions: How to Turn Browsers into Buyers, Journal of Marketing Theory and Practice, 12 (3), 36-48.

11. Levin, A. M., I. P. Levin, and C. E. Heath, 2003, Product Category Dependent Consumer Preferences for Online and Offline Shopping Features and their Influence on Multi-Channel Retail Alliances, Journal of Electronic Commerce Research, 4(3), 85-93.

12. Newbery, M., 2004, Trends in Apparel Online Retailing, Forecasts to 2010, Just in Style, 1-8.

13. Monsuwe, Perea y, T., B. Dellaert and K. de Ruyter, 2004, What Drives Consumers to Shop Online? A Literature Review, International Journal of Service Industry Management, 15(1), $102-122$.

14. Preston-Hubbard, H. April 17, 2004, Growth Drives Revival in Internet Shares, International Herald Tribune.

15. Reinhardt, A., 2004, Europe Hits the E-Mall, Business Newsweek, 51-52.

16. Sager, I. and H. Green, 2002, So Where Are All the Bargains?, Business Week, 162-164.

17. Schaupp, L. and F. Bélanger, 2005, A Conjoint Analysis of Online Consumer Satisfaction, Journal of Electronic Consumer Research, 6(2), 95-111.

18. Schoenbachler, D. and G. Gordon, 2002, Multichannel Shopping: Understanding What Drives Channel Choice, The Journal of Consumer Marketing, 19(1), 42-54.

19. Stafford, T.H., A. Turan and M. Raisinghani, 2004, International and Cross-Cultural Influences on Online Shopping Behavior, Journal of Global Information Technology Management, $7(2), 70-88$.

20. Swinyard, W. R. and S. M. Smith, 2003, Why People (Don't) shop Online: A Lifestyle Study of the Internet Consumer, Psychology and Marketing, 20, 567-597.

21. Tamimi, N., Sebastianelli, R. \& Rajan M., 2005, What Do Online Customers Value?, Quality Progress, 38(7), 35-40.

22. Van Slyke, C., C. Comunale and F. Bélanger, 2002, Gender Differences Perceptions of WebBased Shopping, Communications of the ACM, 45(8), 82-86.

23. Zhou, L., W. K. Chiang, and D. Zhang, 2004, Discovering Rules for Predicting Customers' Attitude Toward internet Retailers, Journal of Electronic Commerce Research, 5(4), 228-238 